\title{
MIKROALGA TECHNOLÓGIA ALKALMAZHATÓSÁGÁNAK LEHETŐSÉGEI
}

\section{UTILISATION POSSIBILITIES OF MICROALGA TECHNOLOGY}

\author{
Hodai Zoltán ${ }^{1}$, Rippelné Pethő Dóra ${ }^{2}$, Horváth Géza ${ }^{3}$, Hanák László ${ }^{4}$, \\ Bocsi Róbert ${ }^{5}$ \\ 1,2,3,4,5 Pannon Egyetem, Mérnöki Kar, Vegyipari Müveleti Intézeti Tanszék, H-8200, \\ Magyarország, Veszprém, Egyetem utca 10. Telefon: +36(88)624-132, Fax: \\ +36(88)642-446, H-8201 Veszprém, Pf. 158. \\ 'hodaiz@almos.uni-pannon.hu \\ 2pethod@almos.uni-pannon.hu \\ 3horvathg@almos.uni-pannon.hu \\ 4hanakl@almos.uni-pannon.hu \\ 5bocsirobert@almos.uni-pannon.hu
}

\begin{abstract}
A new technology in Hungary is presented by the author wich is able to reduce the emission of industrial pollutants. This technology is referred to as algae technology in the literature. Because of the high operational costs and long operational times, the critical point of this technology is the processing. For the preparation of algae suspensions photo-bioreactors where designed and built. The quick and economical separation of the algae mass from the nutrient solution, were investigated by taking environmental protection and economic aspects into consideration. Experiments were also conducted in order to enhance the stability and the storage life of the concentrated biomass.
\end{abstract}

Keywords: algae technology, carbon dioxide absorption, photobioreactor, separation, utilisation.

\section{Összefoglalás}

A szerző a dolgozatban az ipari szennyezőanyagok kibocsátását csökkentő, Magyarországon új megoldást, technológiát mutat be, amelyet a szakirodalom algatechnológiának nevez. A technológia kritikus pontját a feldolgozási müveletek jelentik, a magas beruházási és üzemeltetési költségek és a nagy műveleti idők miatt. Az alga szuszpenziók előállításához foto-bioreaktorokat tervezett és épített meg. Vizsgálta az algatömeg gyors és gazdaságos szeparálását a tápoldattól, a környezetvédelmi és gazdasági szempontok figyelembevételével. Kísérleteket végzett a besürített biomassza stabilitásának, tárolhatóságának növelésére.

Kulcsszavak: algatechnológia, széndioxid elnyeletés, foto-bioreaktor, szeparáció, felhasználás 


\section{Bevezetés}

Egyre nagyobb figyelmet kapnak az olyan technológiák, melyek a kibocsátott szennyezöanyagokat számunkra hasznos anyagokká alakítják át, így csökkentve a kibocsátás mennyiségét [1-4].

Energiatermelés szempontjából is a fotoszintetizáló mikroszkopikus élőlények (mikroalgák) jönnek elsősorban számításba, mert viszonylag gyorsan, nagy tömegben termeszthetök, termőtalaj igénye nélkül. A folyamat végterméke, amit biomasszának hívunk, jelentős mennyiségü, kémiai kötésekben raktározott napenergiát tartalmaz [57]. A technológia kritikus pontját a feldolgozási müveletek jelentik, a mikroalgaszuszpenzió besürítése és az ezt követő kulcskomponens(ek) extrakciója - és egyéb kinyerési technikák értékes komponensekre - a magas beruházási és üzemeltetési költségek és a nagy műveleti idők miatt $[8,9]$.

\section{Algatechnológia felhasználásá- nak lehetőségei}

\subsection{A jövő építészete}

Az algatechnológiának egy speciális, futurisztikus lehetősége az épületgépészeti hasznosítása. A Pompidou Centre, a Sydney Operaház és a pekingi olimpia egyes stadionjainak terveiért felelős Arup tervezőiroda belső kutatóközpontjának elképzelései szerint a jövő felhőkarcolóit algák látják majd el energiával, az épület pedig alkalmazkodik a felhasználókhoz. Josef Hargrave, az Arup „It's Alive” címü tanulmányának szerzője szerint az ilyen típusú épületek alkalmazkodni képes organizmusokká válnak, amelyek élelmet is adnak, sőt, a víz és a levegő tisztításából is kiveszik részüket. A Hargrave által 2050-re elképzelt sokemeletes házak színe az UV-sugárzás mértékétől függően változik [10], köszönhetően a beépített algatechnológiának.

\subsection{Emberi táplálék}

A Spirulina egyike a legjobb minőségü, nem állati eredetủ fehérjeforrásoknak, mely a Föld élelmezésének jelentős részét képezhetné. Ma az algákat a világ legnagyobb élelmiszer tartalékaként tartják számon a tápanyagsürüségük miatt. Két fajtájuk áll különösen érdeklödés középpontjában: a Spirulina és a Chlorella. A mikroalgák színanyagai akár ételek természetes színezékeként is felhasználhatóak, akár funkcionális élelmiszerek létrehozásában is [11].

\subsection{Kozmetikai ipar}

Az algákat hosszú ideje alkalmazzák kozmetikai készítményekben illetve szájon át kozmetikai célokra is, mivel koncentráltan tartalmazhatnak különféle bioaktív anyagokat. A Spirulinából készült termékekben a karotinoid vegyületek és más színanyagok, illetve az E-vitamin antioxidáns, oxidatív stresszt kivédő hatását használják fel.

\subsection{Mezőgazdasági hasznosítás}

Az algákat biotrágyaként és talajkondicionálóként egyaránt alkalmazzák, de az utóbbi időben növekszik az érdeklődés antimikrobiális- és a növényi növekedést szabályozó, úgynevezett $P G R$-anyagaik iránt is. Számos hasznos tulajdonságukkal és kedvező hatásukkal befolyásolják a növény-talajrendszereket. Az algák olyan speciális anyagokat tartalmaznak, amelyeknek igen nagy a kereskedelmi értéke. Ilyenek például a hosszú szénláncú, többszörösen telítetlen zsírsavak (eikozapentaén-sav: $E P A$, dokozahexaén-sav: $D H A$ ) és a karotinok [12]. Az alga használható a termés minőségének, hozamának javítására, másodsorban pedig növényvédelmi célra. Az algák által termelt anyagok úgynevezett elicitorként hatnak, tehát magában a növényben váltanak ki olyan élettani folyamatokat, amelyek következtében kevésbé lesz fogékony a betegségekre. A másik módja, hogy az alga közvetlenül hat a gombára, 
gátolja a szaporodását vagy elpusztítja, és így védi meg a növényt. Az alga tehát növényi tápanyag, növényvédő szer és talajjavító is [13].

\subsection{Biopolimer-ipar}

Az algák számos előnyös tulajdonságuknak köszönhetően, jól alkalmazhatóak a biopolimer-ipari alapanyagaként is. Az algákból készült biopolimerek gyártása a bioüzemanyagok gyártása során fejlődött ki, mint kísérő iparág. Bár napjainkban ez a megoldás még gyerekcipőben jár, a jövőben az üzemi előállítás megvalósulásával az alga-alapú biopolimerek széles körü alkalmazása várható [14].

\subsection{Bioenergetika}

Új irány az ipari, energetikai szektorban történő felhasználás. Az elmúlt években a fosszilis energiahordozók egyre költségesebb kitermelhetősége miatt folyamatosan nő az alternatív üzemanyagok igénye. A biodízel az olajnövényeken kívül jó hatásfokkal állítható elő nagy lipidtartalmú mikroalgákból is. Biodízel keverőkomponensként használva az algából kinyert lipideket, és a káros anyag kibocsátását összevetve a biodízel emissziós értékeivel, pozitív mérleget mutatott [15]. Az algatechnológia ilyen irányú felhasználhatósága nagyban függ a kőolaj árak, és az üzemanyag árak jövőbeni alakulásától [16].

\section{Algatechnológiai termesztő- rendszerek}

A MOL Magyar Olaj- és Gázipari Nyrt. Dunai Finomítójának területén félüzemi méretben megterveztünk és megépítettünk egy zárt termesztő rendszert $(\sim 0,2$ $\mathrm{m}^{3} /$ reaktoregység). A fent említett finomítói környezetben egy nyílt, mobilis termesztőreaktort is kiépítettünk ( $0,4 \mathrm{~m}^{3} /$ reaktor $)$, amelyet magas termelékenység, jó fotoszintetikus hatásfok (4-6\%), jó beadagolt $\mathrm{CO}_{2}$ hasznosulás (10-35\%) és magas termék koncentráció $\left(\mathrm{c}_{\mathrm{Alga}}=1-2 \mathrm{~kg} / \mathrm{m}^{3}\right)$ jellemez.
Az utóbb installált foto-bioreaktor kialakítása révén (szabályzó és adatgyüjtő rendszerrel felszerelt, áttetsző plexi kialakítású) lehetőséget nyújt szabadtéri-nyílt termesztő tavak müködésének megfigyelésére, modellezésére és így az optimális müködési paramétereinek és méretének meghatározására. A szóban forgó rendszerek jó alapokat biztosítanak egy nagy biomassza kapacitású és alacsony beruházási valamint üzemeltetési költségigényü termesztő rendszer kialakításához. Az így megtermelt biomassza szuszpenzió szeparációjára, gazdaságos, jól alkalmazható szeparációs müveletet fejlesztettünk ki [17].

\section{Következtetések}

Szakirodalmak alapján a mikroalga alapú biodízel mindaddig nem versenyképes a kőolaj alapú üzemanyagokkal szemben, amíg a technológia kihozatala nincs az energiaminimalizálással párhuzamosan maximálva. A technológia csak úgy életképes, ha figyelembe vesszük a szennyvíztisztítást, a füstgáz tisztítása mellett és a megtermelt mikroalgából egyéb értékes termékek értékét is $[4,18]$.

A megépített rendszereink jó alapokat biztosítanak egy nagy biomassza kapacitású és alacsony beruházási, valamint üzemeltetési költségigényü termesztő rendszer kialakításához. A jelenlegi olajárakkal az algák azonban nem versenyezhetnek, energetikai felhasználásuk nem rentábilis, így egyéb tulajdonságaik miatt további hasznosítási területeket (biopolimer ipar, szennyvíztisztítás, mezőgazdaság, kozmetikai ipar, étrend kiegészítők, stb.), cégeket lehet érdemes megcélozni.

\section{Köszönetnyilvánítás}

A kutatás a TÁMOP 4.2.4.A/2-11-12012-0001 Nemzeti Kiválóság Program címü kiemelt projekt keretében zajlott. A projekt az Európai Unió támogatásával, az Európai Szociális Alap társfinanszírozásával valósul meg. 


\section{Szakirodalmi hivatkozások}

[1] David Dah-Wei Tsai, Rameshprabu Ramaraj, Paris Honglay Chen: Growth condition study of algae function in ecosystem for $\mathrm{CO}_{2}$ bio-fixation, Journal of Photochemistry and Photobiology B: Biology, 2012, 27-34.

[2] G. Venkata Subhash, Rashmi Chandra, S. Venkata Mohan: Microalgae mediated bioelectrocatalytic fuel cell facilitates bioelectricity generation through oxygenic photomixotrophic mechanism, Bioresource Technology, 2013, 644-653.

[3]Raphael Slade, Ausilio Bauen: Micro-algae cultivation for biofuels: Cost, energy balance, environmental impacts and future prospects, Biomass and Bioenergy, 2013, 29-38

[4]Melissa Rickman, John Pellegrino, Jason Hock, Stephanie Shaw, Brice Freeman: Lifecycle and techno-economic analysis of utilityconnected algae systems, Algal Research, 2013, 59-65.

[5]A. Ruiz-Martinez, N. Martin Garcia, I. Romero, A. Seco, J. Ferrer: Microalgae cultivation in wastewater: Nutrient removal from anaerobic membrane bioreactor effluent, Bioresource Technology, 2012, 247-253.

[6] Sunja Cho, Nakyeong Lee, Seonghwan Park, Jaecheul Yu, Thanh Thao Luong, You-Kwan Oh, Taeho Lee: Microalgae cultivation for bioenergy production using wastewaters from a municipal WWTP as nutritional sources, Bioresource Technology, 2013, 515-520.

[7] David Dah-Wei Tsai, Rameshprabu Ramaraj, Paris Honglay Chen: Growth condition study of algae function in ecosystem for $\mathrm{CO}_{2}$ biofixation, Journal of Photochemistry and Photobiology B: Biology, 2012, 27-34.

[8] Truc Linh Nguyen, D.J. Lee, J.S. Chang, J.C. Liu: Effects of ozone and peroxone on algal separation via dispersed air flotation, Colloids and Surfaces B: Biointerfaces, 2013, 246250.

[9] Ryan Davis, Andy Aden, Philip T. Pienkos: Techno-economic analysis of autotrophic microalgae for fuel production, Applied Energy, 2011, 3524-3531.

[10] Report describes the future of buildings in 2050, Arup launches 'It's Alive' - a new report that describes how buildings in our cities could look and function in 2050, $04 \mathrm{Feb}$ 2013.

[11] MDOSZ-Táplálkozási Akadémia hírlevél III. évfolyam 8. szám, 2010.

[12] Sweetman E.: Microalgae: its applications and potential. International Aqua Feed. Perendale Publishers Ltd. UK., 2009.

[13] http://m.innoteka.hu/cikk/algak_a_novenyte rmesztesben.100.html, letöltve: 2013 .

[14] oilgae.com, letöltve 2013.

[15] Anita Kirrolia, Narsi R. Bishnoi, Rajesh Singh: Microalgae as a boon for sustainable energy production and its future research \&amp; development aspects, Renewable and Sustainable Energy Reviews, 2013, 642-656

[16] Gustavo B. Leite, Ahmed E.M. Abdelaziz, Patrick C. Hallenbeck: Algal biofuels: Challenges and opportunities, Bioresource Technology, 2013, 134-141.

[17] Zoltan Hodai, Dora Rippel-Petho, Geza Horvath, Laszlo Hanak, Robert Bocsi: New bio-flocculatious effect and its examination, World Journal of Engineering and Technology, 2014, 116-123.

[18] Mark T. Holtzapple, Frank E. Little, William M. Moses, C.O. Patterson: Analysis of an algae-based celss: Part 2: Options and weight analysis, Acta Astronautica, 1989, 365-375. 